\title{
Protection by Antibiotics against Myeloperoxidase-dependent Cytotoxicity to Lung Epithelial Cells In Vitro
}

\author{
André Cantin and Donald E. Woods * \\ Unité de Recherche Pulmonaire, Centre Hospitalier Universitaire de Sherbrooke, Sherbrooke, Quebec, Canada J1H 5 N4; \\ and * Department of Microbiology and Infectious Diseases, Health Sciences Centre, Calgary, Alberta, Canada T2N 4NI
}

\begin{abstract}
Myeloperoxidase, in the presence of noncytotoxic concentrations of $\mathrm{H}_{2} \mathrm{O}_{2}$, was used to induce cytotoxicity to the lung epithelial cell line, AKD. When the cationic aminoglycosides, tobramycin and gentamicin were added to the cells in the presence of myeloperoxidase and $\mathrm{H}_{2} \mathrm{O}_{2}$, cytotoxicity was completely inhibited. In addition, tobramycin prevented cytotoxicity induced by cystic fibrosis sputum and $\mathrm{H}_{2} \mathrm{O}_{2}$. Protection against myeloperoxidase and $\mathrm{H}_{2} \mathrm{O}_{2}$ was also observed with the thioether-containing antibiotics, ticarcillin and ceftazidime, but at higher concentrations than with the aminoglycosides. Analysis of spectral properties, dimethylsulfoxide-mediated reduction, and ethyl acetate $/ \mathrm{NaCl}$ partitioning, demonstrated that aminoglycosides converted $\mathrm{HOCl}$ to hydrophilic noncytotoxic chloramines, but were unable to prevent the oxidation of sulfhydryls and methionine by $\mathrm{HOCl}$. In contrast, ticarcillin and ceftazidime were highly effective inhibitors of $\mathrm{HOCl}$-mediated sulfhydryl and methionine oxidation. These results suggest that aminoglycosides protect lung epithelial cells against myeloperoxidase-dependent oxidant injury by binding to anionic cell surfaces and converting $\mathrm{HOCl}$ to hydrophilic noncytotoxic chloramines, whereas penicillins and cephalosporins are potent HOCl scavengers capable of protecting critical extracellular molecules against oxidation. (J. Clin. Invest. 1993.91:38-45.) Key words: chloramines $\bullet$ cystic fibrosis $\bullet$ hypochlorite $\bullet$ myeloperoxidase $\bullet$ oxidants
\end{abstract}

\section{Introduction}

Chronic inhalation of antibiotics effective against Pseudomonas aeruginosa has been shown to reduce the number of hospital admissions and the rate of pulmonary function deterioration in patients with cystic fibrosis (CF). ${ }^{1}$ The benefits of this therapy are observed despite evidence that Pseudomonas aeruginosa is rarely eradicated from the CF lung and that up to one third of patients receiving inhaled antibiotics develop resistant strains within their bronchial secretions (1-5).

\footnotetext{
Address reprint requests to Dr. Cantin, Pneumologie, CHUS, $300112 \mathrm{e}$ Ave Nord, Sherbrooke, QC, Canada J1H 5 N4.

Received for publication 6 August 1991 and in revised form 1 June 1992.
}

1. Abbreviations used in this paper: ARDS, adult respiratory distress syndrome; CF, cystic fibrosis; EBSS, Earle's balanced salt solution; IPF, idiopathic pulmonary fibrosis.

J. Clin. Invest.

(c) The American Society for Clinical Investigation, Inc.

$0021-9738 / 93 / 01 / 38 / 08 \$ 2.00$

Volume 91, January 1993, 38-45
Bronchial secretions from CF patients contain bacteria, neutrophils, and their respective toxic products (6-8). Both Pseudomonas and activated neutrophils are capable of releasing significant amounts of hydrogen peroxide $\left(\mathrm{H}_{2} \mathrm{O}_{2}\right)(9,10)$. In addition, Mohammed et al. (11) have demonstrated that $\mathrm{CF}$ bronchial secretions have high concentrations of myeloperoxidase, a neutrophil-derived enzyme which, in the presence of $\mathrm{H}_{2} \mathrm{O}_{2}$, converts chloride to toxic hypochlorous acid/hypochlorite anion $\left(\mathrm{HOCl} / \mathrm{OCl}^{-1}\right.$, but abbreviated as $\mathrm{HOCl}$ for simplicity). These studies suggest that CF airway cells are at risk of oxidant-mediated injury, and that essential molecules at the CF respiratory epithelial surface, such as $\alpha_{1}$-antitrypsin, may undergo oxidative inactivation. In this context, protection of airway epithelial cells and extracellular molecules against HOCl-mediated oxidant damage could conceivably be beneficial to CF patients.

$\mathrm{HOCl}$ is a strong oxidant which reacts readily with various chemical groups including primary amines, thiols and thioethers $(12,13)$. Aminoglycosides, such as gentamicin and tobramycin, have multiple primary amines, whereas ticarcillin and ceftazidime each contain two thioether groups, all of which may potentially react with $\mathrm{HOCl}$ (Fig. 1). These antibiotics are among some of the anti-Pseudomonas aeruginosa agents most commonly administered intravenously and by aerosolization to $\mathrm{CF}$ patients. We hypothesized that, in addition to their microbicidal activity, these antibiotics may have significant antioxidant properties. The present study was designed to determine whether tobramycin, gentamicin, ticarcillin, and ceftazidime can protect lung epithelial cells, methionine, and thiol groups in vitro against myeloperoxidase-derived oxidants.

\section{Methods}

Cytotoxicity assay. The cat lung epithelial cell line, AKD (CCL 151; American Type Culture Collection, Rockville, MD) (14) was used as the target cell for all cytotoxicity experiments, as previously described (15). The cells were seeded at a density of 50,000 cells per well in 24-well culture plates (Linbro Chemical Co., New Haven, CT) in 0.5 $\mathrm{ml}$ of Dulbecco's modified Eagle's medium (DME, Gibco Diagnostic Laboratories, Grand Island, NY) supplemented with $10 \%$ calf serum, in $10 \% \mathrm{CO}_{2}$ at $37^{\circ} \mathrm{C}$. At confluence, the cells were labeled with sodium chromate $\left({ }^{51} \mathrm{Cr}, 22 \mathrm{mCi} / \mathrm{nmol}, 5 \mu \mathrm{Ci}\right.$ per cell $)$ overnight and subsequently washed three times with PBS. Earle's balanced salt solution (EBSS), $0.5 \mathrm{ml}$, was added to each well and the cells were incubated in the presence of either EBSS alone or various test conditions ( see below) for $7 \mathrm{~h}$ in $5 \% \mathrm{CO}_{2}$ at $37^{\circ} \mathrm{C}$. Maximum ${ }^{51} \mathrm{Cr}$ release was assessed by incubating the cells with $1 \%$ Triton-X (J.T. Baker Chemical Co., Phillipsburg, NJ). Spontaneous release of ${ }^{51} \mathrm{Cr}$ was determined in the presence of EBSS alone. At the end of the incubation period, the amount of ${ }^{51} \mathrm{Cr}$ released in the supernatant of each test condition was quantitated. ${ }^{51} \mathrm{Cr}$ release did not reflect cell detachment since centrifugation of samples prior to measurement of ${ }^{51} \mathrm{Cr}$ in the supernatant did not change the results. A cytotoxicity index was determined according to the following 


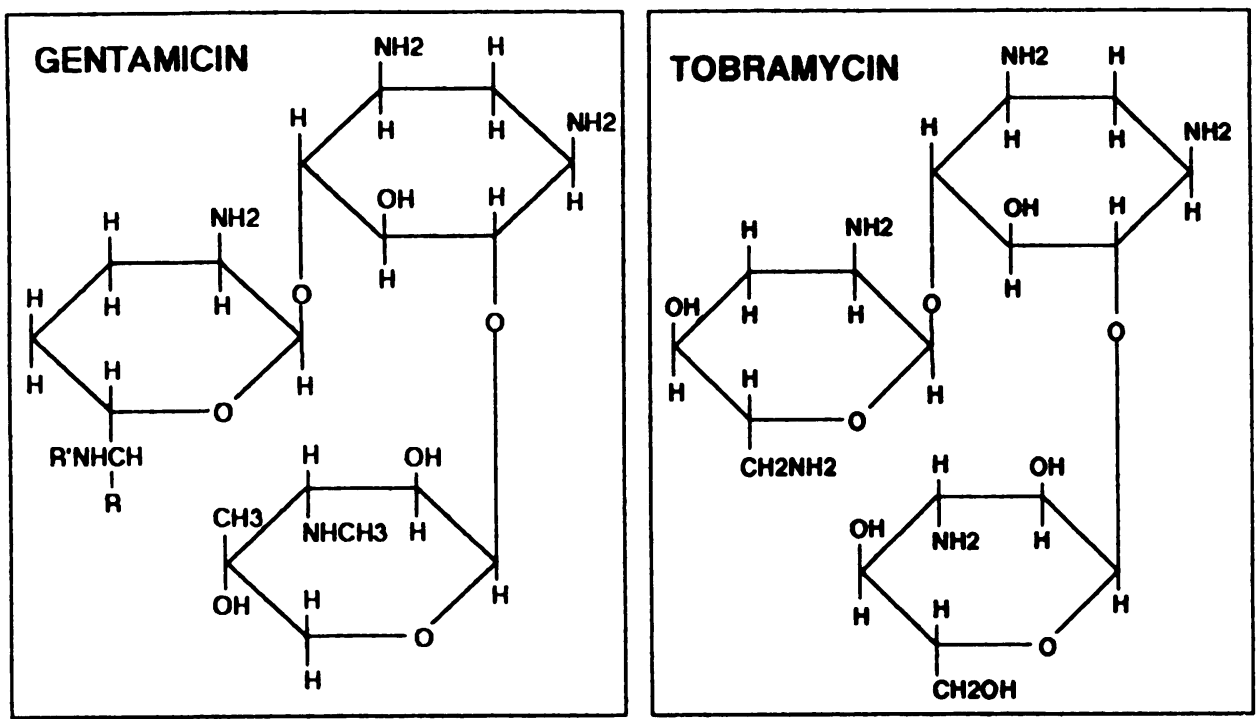

TICARCILLIN

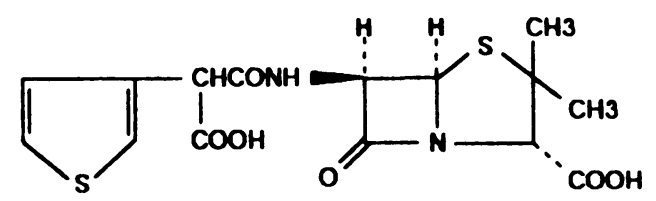

Figure 1. Chemical structures of gentamicin, tobramycin, ticarcillin, and ceftazidime. Both aminoglycosides have multiple primary amines $\left(-\mathrm{NH}_{2}\right)$. Ticarcillin and ceftazidime each have 2 thioether groups (-R-SR-). formula: cytotoxicity index $=(A-B) /(C-B) \times 100$, where $A$ is dpm of the test sample, $B$ is dpm of spontaneous release, and $C$ is dpm of $1 \%$ Triton-X-treated cells.

Myeloperoxidase and HOCl-induced cytotoxicity. Myeloperoxidase was purified from granulocytes obtained by leukophoresis of a patient with chronic myeloid leukemia, according to the methods of Matheson et al (16). The $A_{430} / A_{280}$ ratio (Reinheit Zahl purity number) of the purified material was 0.82 , a value similar to the Reinheit Zahl number of 0.83 reported for $100 \%$ pure human myeloperoxidase (17). The labeled cells were incubated with various concentrations $(0-5 \mu \mathrm{g} / \mathrm{ml})$ of myeloperoxidase for $1 \mathrm{~h}$, followed by the addition of $150 \mu \mathrm{M} \mathrm{H}_{2} \mathrm{O}_{2}$ to the culture media for $7 \mathrm{~h}$ in an atmosphere of $5 \% \mathrm{CO}_{2}$ at $37^{\circ} \mathrm{C}$. The effect of incubation time of myeloperoxidase before the addition of $\mathrm{H}_{2} \mathrm{O}_{2}$, on cytotoxicity was assessed by adding $2.5 \mu \mathrm{g} / \mathrm{ml}$ myeloperoxidase to the cells and subsequently adding $150 \mu \mathrm{M} \mathrm{H}_{2} \mathrm{O}_{2}$ at 0-60 min after the addition of myeloperoxidase. The cells were then incubated for $7 \mathrm{~h}$ and the cytotoxicity index determined as described above. Based on the results of these experiments, all subsequent experiments were performed using the conditions that induced maximal cytotoxicity, i.e., $2.5 \mu \mathrm{g} / \mathrm{ml}$ myeloperoxidase added to the media $1 \mathrm{~h}$ before the addition of $150 \mu \mathrm{M} \mathrm{H}_{2} \mathrm{O}_{2}$.

To determine whether cytotoxicity was induced by myeloperoxidase-derived oxidants, cells were incubated with either $(a) 2.5 \mu \mathrm{g} / \mathrm{ml}$ of myeloperoxidase, (b) $150 \mu \mathrm{M} \mathrm{H}_{2} \mathrm{O}_{2}$, (c) myeloperoxidase $+\mathrm{H}_{2} \mathrm{O}_{2}$, (d) heat-inactivated myeloperoxidase $\left(100^{\circ} \mathrm{C}\right.$ for $\left.10 \mathrm{~min}\right)+\mathrm{H}_{2} \mathrm{O}_{2},(e)$ myeloperoxidase $+\mathrm{H}_{2} \mathrm{O}_{2}+100 \mathrm{U} / \mathrm{ml}$ of catalase, $(f)$ myeloperoxi- dase $+\mathrm{H}_{2} \mathrm{O}_{2}+100 \mathrm{U} / \mathrm{ml}$ of heated catalase, $(g)$ myeloperoxidase $+\mathrm{H}_{2} \mathrm{O}_{2}+500 \mu \mathrm{M}$ [GSH], glutathione, reduced or $(h)$ myeloperoxidase $+\mathrm{H}_{2} \mathrm{O}_{2}+500 \mu \mathrm{M}$ methionine.

To determine whether antibiotics affected myeloperoxidase activity, $2.5 \mu \mathrm{g} / \mathrm{ml}$ of myeloperoxidase was incubated alone or with $200 \mu \mathrm{M}$ of either tobramycin, gentamicin, ceftazidime, or ticarcilline in EBSS for $7 \mathrm{~h}$, and myeloperoxidase activity was measured spectrophotometrically with the substrate $o$-dianisidine as previously described (18).

Antibiotic protection of lung cells against oxidant injury. The protective effects of the antibiotics against myeloperoxidase $+\mathrm{H}_{2} \mathrm{O}_{2}$-mediated cytotoxicity were determined by adding $0-200 \mu \mathrm{M}$ of each antibiotic to the cells in the presence of $2.5 \mu \mathrm{g} / \mathrm{ml}$ myeloperoxidase for $1 \mathrm{~h}$, followed by the addition of $150 \mu \mathrm{M} \mathrm{H}_{2} \mathrm{O}_{2}$ for $7 \mathrm{~h}$ as described above. In that $\mathrm{HOCl}$ is the major toxic species synthesized by myeloperoxidase and $\mathrm{H}_{2} \mathrm{O}_{2}$ at physiologic $\mathrm{pH}(19)$, similar assays were performed by replacing myeloperoxidase and $\mathrm{H}_{2} \mathrm{O}_{2}$ with $150 \mu \mathrm{M} \mathrm{HOCl}$.

Cytotoxicity from $\mathrm{CF}$ sputum and $\mathrm{H}_{2} \mathrm{O}_{2}$. Sputum was obtained from two patients (aged 19 and 21 yr, nonsmokers) with cystic fibrosis, during an acute exacerbation of their lung disease. Neither was taking antibiotics at the time of sputum collection. The sputum was homogenized in $0.05 \mathrm{M}$ potassium phosphate buffer, $\mathrm{pH} 7.0$ (1:1 wt/vol), centrifuged $15,000 \mathrm{~g}, 15 \mathrm{~min}$ at $20^{\circ} \mathrm{C}$ and the supernatant was eluted from a PD-10 column (Pharmacia Fine Chemicals, Piscataway, NJ) with EBSS. The eluate was passed through a $0.22-\mu \mathrm{m}$ filter and 0-250 $\mu \mathrm{l}$ was added to the ${ }^{51} \mathrm{Cr}$-labeled cells in the absence and presence of 200 $\mu \mathrm{M}$ tobramycin, and the final volume was adjusted to $500 \mu \mathrm{l}$ with 
EBSS. The cells were incubated for $1 \mathrm{~h}$, and subsequently either EBSS or $150 \mu \mathrm{M} \mathrm{H}_{2} \mathrm{O}_{2}$ was added to the media for $7 \mathrm{~h}$ at $37^{\circ} \mathrm{C}, 5 \% \mathrm{CO}_{2}$. The media from the cells was then harvested, centrifuged $(500 \mathrm{~g}, 5 \mathrm{~min}$ ) and the supernatant was collected to determine the cytotoxicity index. Each condition was evaluated in triplicate.

Thiol and methionine oxidation. To evaluate the capacity of the antibiotics to prevent $\mathrm{HOCl}$-induced oxidation of thiol and methionine, $40 \mu \mathrm{M} \mathrm{HOCl}$ was incubated with $0-80 \mu \mathrm{M}$ gentamicin, tobramycin, ticarcillin, or ceftazidime in EBSS for $15 \mathrm{~min}$ at $25^{\circ} \mathrm{C}$. Subsequently, either $80 \mu \mathrm{M}$ 5-thio-2-nitrobenzoic acid, prepared by adding 4 $\mu l$ 2-mercaptoethanol to $1 \mathrm{mM}$ dithiobis-nitrobenzoic acid as in Thomas et al. (20), or $100 \mu \mathrm{M}$ methionine (Sigma Chemical Co., St. Louis, MO) was added to each sample for $15 \mathrm{~min}$ at $25^{\circ} \mathrm{C}$. The residual concentration of 5-thio-2-nitrobenzoic acid was determined by measuring the absorbance of each solution at $412 \mathrm{~nm}$, assuming an $\Sigma_{M}$ $=13,600(20)$.

The ratio of methionine to methionine + methionine sulfoxide was measured immediately after the incubation period by reverse-phase high-pressure liquid chromatography (HPLC), using a modification of the method described by Turnell and Cooper (21). Precolumn derivatization was performed by adding $20 \mu \mathrm{l}$ sample to $20 \mu \mathrm{l} o$-phthaldialdehyde reagent for $2 \mathrm{~min}$. The $\sigma$-phthaldialdehyde reagent was composed of $5.5 \mathrm{mg} o$-phthaldialdehyde dissolved in $1 \mathrm{ml}$ of methanol to which was added $9 \mathrm{ml}$ of $0.5 \mathrm{M}$ potassium borate, $\mathrm{pH} 9.5$, containing $40 \mu \mathrm{l}$ of 2-mercaptoethanol. The analytical column was $150 \times 4.6 \mathrm{~mm}$ i.d. and prepacked with $5 \mu \mathrm{m}$ Ultrasphere octadecyl silane (Beckman Instruments Inc., Palo Alto, CA). Solvent A was water and solvent B was methanol. The HPLC apparatus was a Beckman System Gold with a 166 detector set at $340 \mathrm{~nm}$. The gradient, expressed as percentage of solvent B, was brought from 0 to $9 \%$ over $1 \mathrm{~min}$, to $11 \%$ over $10 \mathrm{~min}$, to $20 \%$ over $1 \mathrm{~min}$, held at $20 \%$ for $2 \mathrm{~min}$, and brought to $25 \%$ over 10 min. Methionine sulfoxide was detected at $8.5 \mathrm{~min}$ and methionine at $18.8 \mathrm{~min}$.

Characterization of aminoglycoside $\mathrm{N}$-Cl derivatives. The products of the reaction of aminoglycosides with $\mathrm{HOCl}$ were characterized by $(a)$ analysis of their spectral properties, $(b)$ their susceptibility to reduction by dimethylsulfoxide (DMSO), and $(c)$ their lipophilicity.

Spectral properties of the aminoglycoside $+\mathrm{HOCl}$ product (s) were analyzed by incubating $500 \mu \mathrm{l}$ of EBSS or $500 \mu \mathrm{l}$ of either $400 \mu \mathrm{M}$ gentamicin or tobramycin with $500 \mu \mathrm{l}$ of $400 \mu \mathrm{M} \mathrm{HOCl}$ for 5 min at $25^{\circ} \mathrm{C}$. The absorbance of each solution was measured at wavelengths 310-230 nm in a DU-7 scanning spectrophotometer (Beckman Instruments Inc.). Each sample was measured against a control sample containing either gentamicin or tobramycin in EBSS.

Since DMSO can reduce $\mathrm{HOCl}$ but not chloramines (20), the susceptibility of the aminoglycoside $+\mathrm{HOCl}$ reaction product(s) to reduction by DMSO was assessed. PBS solution, $\mathrm{pH} 7.4$, (PBS), $200 \mu \mathrm{M}$ tobramycin, or $200 \mu \mathrm{M}$ gentamicin were incubated with either $40 \mu \mathrm{M}$ $\mathrm{HOCl}$ or PBS for $15 \mathrm{~min}$ at $25^{\circ} \mathrm{C}$. An equal volume of either PBS or $200 \mu \mathrm{M}$ DMSO was then added to each sample for $5 \mathrm{~min}$ at $25^{\circ} \mathrm{C}$.
Subsequently, $60 \mu \mathrm{M}$ 5-thio-2-nitrobenzoic acid was added to each sample for $15 \mathrm{~min}$ at $25^{\circ} \mathrm{C}$, and the amount of residual 5-thio-2-nitrobenzoic acid was determined from the absorbance of each sample at $412 \mathrm{~nm}$ as described above. All experiments were repeated five times.

The lipophilicity of $\mathrm{N}-\mathrm{Cl}$ derivatives from the aminoglycoside $+\mathrm{HOCl}$ reaction was determined according to the method described by Thomas (22). Ethyl acetate was treated with $2.64 \mathrm{mM}$ sodium borohydride and $0.1 \mathrm{M} \mathrm{NaOH}$ for $30 \mathrm{~min}$ to remove contaminating oxidants and acids, and washed extensively with EBSS. Ethyl acetate $3 \mathrm{ml}$, was added to a 3-ml aqueous sample composed of $200 \mu \mathrm{M}$ tobramycin or gentamicin and $40 \mu \mathrm{M} \mathrm{HOCl}$ in EBSS. After phase separation, a 2 -ml portion of the organic phase was mixed with $2 \mathrm{ml}$ of EBSS, to which was added $400 \mu \mathrm{l}$ of $600 \mu \mathrm{M}$ 5-thio-2-nitrobenzoic acid (sample A). Similarly, $400 \mu \mathrm{l}$ of $600 \mu \mathrm{M}$ 5-thio-2-nitrobenzoic acid was added to the remaining portion of the combined aqueous and organic phases (sample B). The absorbance of the aqueous portions of each sample was measured at $412 \mathrm{~nm}$ and the concentration of oxidizing equivalents was determined using the extinction coefficient $\Sigma_{M}=27,200$, since one -RNHCI derivative will oxidize two 5-thio-2-nitrobenzoic acid molecules (22). The concentration of oxidizing equivalents in the organic phase was calculated as 1.5 times that in sample $A$ and the amount in the aqueous phase was calculated as that in sample B minus half that in sample A.

Statistical analysis. All data are expressed as the arithmetic mean \pm SEM. Analysis of variance was performed using the $F$ test, and the Scheffe test was applied to the data when appropriate (23). A $P$ value $<0.05$ was considered significant.

\section{Results}

Myeloperoxidase-mediated cytotoxicity. The dose-response assay of myeloperoxidase-induced cytotoxicity to the epithelial cells, in the presence of $150 \mu \mathrm{M} \mathrm{H}_{2} \mathrm{O}_{2}$, is shown in fig. $2 \mathrm{~A}$. Maximal cytotoxicity was observed at the myeloperoxidase concentration of $2.5 \mu \mathrm{g} / \mathrm{ml}$, a concentration used in all subsequent myeloperoxidase-dependent cytotoxicity assays. The effects of preincubation time of myeloperoxidase with the cells before the addition of $\mathrm{H}_{2} \mathrm{O}_{2}$, are shown in Fig. $2 \mathrm{~B}$. When myeloperoxidase was added to the cells simultaneously with $\mathrm{H}_{2} \mathrm{O}_{2}$, the cytotoxicity index was relatively low (cytotoxicity index at $0 \mathrm{~min}=12.8 \pm 3.3 \%$ ); however, when myeloperoxidase was allowed to incubate with the cells for various periods of time before the addition of $\mathrm{H}_{2} \mathrm{O}_{2}$, a time-dependent enhancement of cytotoxicity was clearly seen (cytotoxicity index at $1 \mathrm{~h}$ $=63.0 \pm 2.5 \%, P<0.001$ compared to $0 \mathrm{~min}$ ). All subsequent experiments were performed with a $1 \mathrm{~h}$ preincubation of the cells and myeloperoxidase before the addition of $\mathrm{H}_{2} \mathrm{O}_{2}$.

Evidence that the myeloperoxidase-dependent injury was mediated by oxidants, likely $\mathrm{HOCl}$, is presented in Table I.
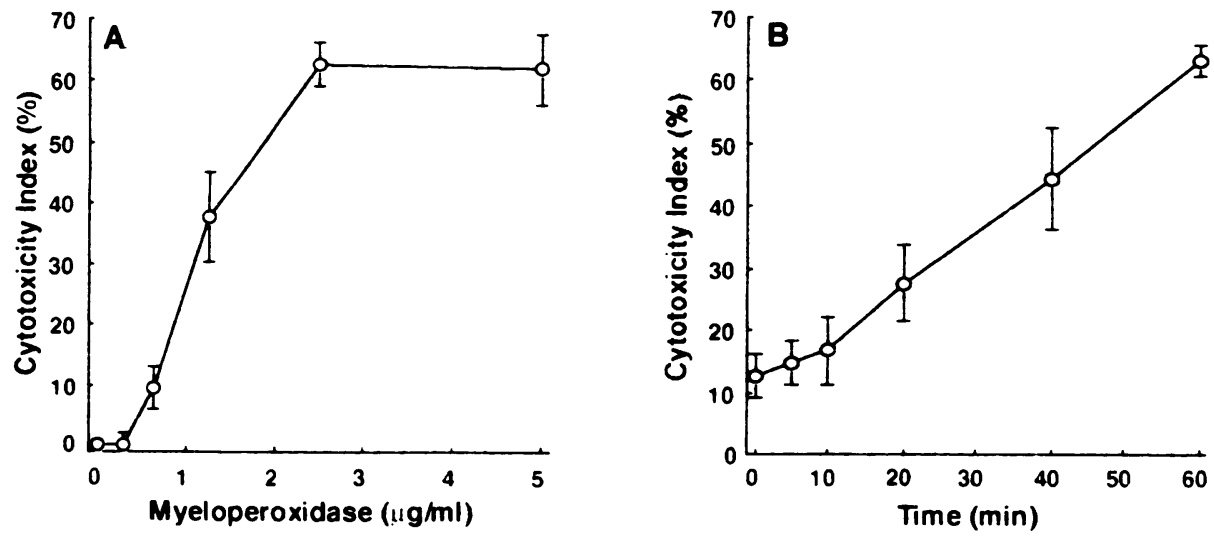

Figure 2. Cytotoxicity assay for evaluating lung epithelial cell injury induced by the $\mathrm{MPO}+\mathrm{H}_{2} \mathrm{O}_{2}$ system. $(A){ }^{51} \mathrm{Cr}$-labeled AKD cells were incubated $1 \mathrm{~h}$ at $37^{\circ} \mathrm{C}$ with various concentrations of myeloperoxidase (MPO). Subsequently, $\mathrm{H}_{2} \mathrm{O}_{2}(150 \mu \mathrm{M})$ was added to the culture medium and the cells were incubated for $7 \mathrm{~h}$, at $37^{\circ} \mathrm{C}$ before the cytotoxicity index was determined. $(B)$ Effect of myeloperoxidase incubation time before $\mathrm{H}_{2} \mathrm{O}_{2}$ addition, on the cytotoxicity index. Each point represents the mean \pm SEM of triplicate cultures. 
Table I. Characterization of the Myeloperoxidase- $\mathrm{H}_{2} \mathrm{O}_{2}$ Cytotoxicity System

\begin{tabular}{lc}
\hline \multicolumn{1}{c}{ Additions } & $\begin{array}{c}\text { Cytotoxicity } \\
\text { index }\end{array}$ \\
\hline & $\%$ \\
$\mathrm{MPO}$ alone & $0.1 \pm 0.3^{*}$ \\
$\mathrm{H}_{2} \mathrm{O}_{2}$ alone & $0.3 \pm 0.5^{*}$ \\
$\mathrm{MPO}+\mathrm{H}_{2} \mathrm{O}_{2}$ & $69.2 \pm 1.2$ \\
$\mathrm{H}$ MPO $+\mathrm{H}_{2} \mathrm{O}_{2}$ & $-0.6 \pm 0.4^{*}$ \\
$\mathrm{MPO}+\mathrm{H}_{2} \mathrm{O}_{2}+$ catalase $100 \mathrm{U} / \mathrm{ml}$ & $-1.9 \pm 0.9^{*}$ \\
$\mathrm{MPO}+\mathrm{H}_{2} \mathrm{O}_{2}+\mathrm{Hi}$ catalase $100 \mathrm{U} / \mathrm{ml}$ & $67.7 \pm 3.6$ \\
$\mathrm{MPO}+\mathrm{H}_{2} \mathrm{O}_{2}+\mathrm{GSH} 500 \mu \mathrm{M}$ & $-1.6 \pm 0.7^{*}$ \\
$\mathrm{MPO}+\mathrm{H}_{2} \mathrm{O}_{2}+$ methionine $500 \mu \mathrm{M}$ & $-4.8 \pm 0.5^{*}$ \\
\hline
\end{tabular}

Abbreviations: MPO, $2.5 \mu \mathrm{g} / \mathrm{ml}$ myeloperoxidase; $\mathrm{H}_{2} \mathrm{O}_{2}, 150 \mu \mathrm{M}$ hydrogen peroxide; $\mathrm{Hi}$, heat-inactivated $\left(100^{\circ} \mathrm{C}\right.$ for $\left.10 \mathrm{~min}\right)$; $\mathrm{GSH}$, glutathione. Values represent the mean \pm SEM of triplicate assays performed on at least two separate occasions. ${ }^{*} P<0.001$ compared to $\mathrm{MPO}+\mathrm{H}_{2} \mathrm{O}_{2}$.

Neither myeloperoxidase nor $\mathrm{H}_{2} \mathrm{O}_{2}$ alone induced cytotoxicity. However, the co-incubation of both agents consistently induced cytotoxicity. Complete inhibition of cytotoxicity was observed in the presence of catalase (but not heat-inactivated catalase), and in the presence of heat-inactivated myeloperoxidase, thus further demonstrating the dependence of cytotoxicity on both $\mathrm{H}_{2} \mathrm{O}_{2}$ and myeloperoxidase. Both glutathione, an antioxidant capable scavenging both $\mathrm{H}_{2} \mathrm{O}_{2}$ and $\mathrm{HOCl}$, and methionine, an $\mathrm{HOCl}$ scavenger without effect on $\mathrm{H}_{2} \mathrm{O}_{2}$-mediated cytotoxicity, protected the cells, implicating $\mathrm{HOCl}$ as the dominant cytotoxic species.

Antibiotics prevent myeloperoxidase and $\mathrm{HOCl}$-dependent cytotoxicity. All four antibiotics tested provided a dose-dependent protection of the lung epithelial cells against myeloperoxidase $/ \mathrm{H}_{2} \mathrm{O}_{2}$-related cytotoxicity (fig. $3 \mathrm{~A}$ ). The antibiotics did not inhibit myeloperoxidase activity (myeloperoxidase alone, $47.1 \pm 2.0 \mathrm{U} / \mathrm{ml}$; + tobramycin, $46.3 \pm 1.0 \mathrm{U} / \mathrm{ml}$; +gentamicin, $47.5 \pm 1.1 \mathrm{U} / \mathrm{ml}$; +ceftazidime, $45.3 \pm 2.0 \mathrm{U} / \mathrm{ml}$; + ticarcillin, $44.6 \pm 0.8 \mathrm{U} / \mathrm{ml}, n=6, P>0.05$ all comparisons). The most efficient antibiotics were tobramycin and gentamicin, which at $50 \mu \mathrm{M}$, decreased the cytotoxicity index from $66.8 \pm 3.3 \%$ to $0 \pm 2 \%$ and from $69.6 \pm 6.7 \%$ to $9.3 \pm 8.9 \%$, respectively ( $P$
$<0.01$, both comparisons). The concentration of tobramycin necessary to provide a reduction of $50 \%$ in the cytotoxicity index was consistently $40-50 \%$ less than that of gentamicin. Ticarcillin and ceftazidime were also protective but only at much higher concentrations than those of the aminoglycosides (200 $\mu \mathrm{M}$ ticarcillin decreased cytotoxicity index from $61.3 \pm 5.2 \%$ to $27.1 \pm 2.4 \%, 200 \mu \mathrm{M}$ ceftazidime decreased the cytotoxicity index from $62.8 \pm 2.8 \%$ to $14.1 \pm 1.8 \%, P<0.01$ both comparisons). In contrast, the protective effects of ticarcillin and ceftazidime against $\mathrm{HOCl}$-induced cytotoxicity were observed within the same concentration range as those of the aminoglycosides (fig. $3 B$ ).

Tobramycin and $\mathrm{CF}$ sputum- $\mathrm{H}_{2} \mathrm{O}_{2}$ cytotoxicity. Sterile-filtered sputum from two CF patients added to the labeled cells at concentrations as high as $250 \mu \mathrm{l} / \mathrm{ml}$ in EBSS did not induce significant cytotoxicity. $\mathrm{H}_{2} \mathrm{O}_{2}$ alone was not cytotoxic, but in the presence of $\mathrm{CF}$ sputum, the cytotoxicity index clearly increased (cytotoxicity index $24 \%$ and $37 \%$ at $250 \mu \mathrm{l} / \mathrm{ml}$ ) (Fig. 4). However, the addition of $200 \mu \mathrm{M}$ tobramycin to the cells before the addition $\mathrm{H}_{2} \mathrm{O}_{2}$ completely inhibited cytotoxicity at all concentrations of sputum from both patients.

Antibiotic $\mathrm{HOCl}$ scavenging properties. $\mathrm{HOCl}$-mediated sulfhydryl oxidation was evidenced by the decrease in 5-thio-2nitrobenzoic acid concentration from $78.6 \pm 0.18$ to $26.8 \pm 1.6$ $\mu \mathrm{M}$ in the presence of $40 \mu \mathrm{M} \mathrm{HOCl}$. Neither tobramycin nor gentamicin prevented 5-thio-2-nitrobenzoic acid oxidation by $\mathrm{HOCl}$ and at $20 \mu \mathrm{M}$ aminoglycoside, the concentration of 5thio-2-nitrobenzoic acid was even decreased compared to $\mathrm{HOCl}$ alone, an effect attributable to the greater stability of choramines than of $\mathrm{HOCl}(20 \mu \mathrm{M}$ tobramycin $+\mathrm{HOCl}$, 5-thio2-nitrobenzoic acid $=17.6 \pm 0.1 \mu \mathrm{M} ; 20 \mu \mathrm{M}$ gentamicin $+\mathrm{HOCl}$, 5-thio-2-nitrobenzoic acid $=18.8 \pm 0.1 \mu \mathrm{M}, P<0.01$, both compared to $\mathrm{HOCl}$ alone) (Fig. $5 \mathrm{~A}$ ). An opposite effect was observed when either ticarcillin or ceftazidime was added to $\mathrm{HOCl}$ in the presence of 5-thio-2-nitrobenzoic acid, with marked protection against thiol oxidation $(25 \mu \mathrm{M}$ ticarcillin $+\mathrm{HOCl}$, 5-thio-2-nitrobenzoic acid $=70.0 \pm 2.6 \mu \mathrm{M} ; 20 \mu \mathrm{M}$ ceftazidime $+\mathrm{HOCl}$, 5-thio-2-nitrobenzoic acid $=69.4 \pm 0.1$ $\mu \mathrm{M}, P<0.001$ compared to $\mathrm{HOCl}$ alone).

Similarly, ticarcillin and ceftazidime, at concentrations of $<10 \mu \mathrm{M}$ efficiently protected methionine from HOCl-dependent oxidation, whereas both tobramycin and gentamicin, even at concentrations as high as $40 \mu \mathrm{M}$, were unable to completely block the formation of methionine sulfoxide (Fig. $5 B$ ).
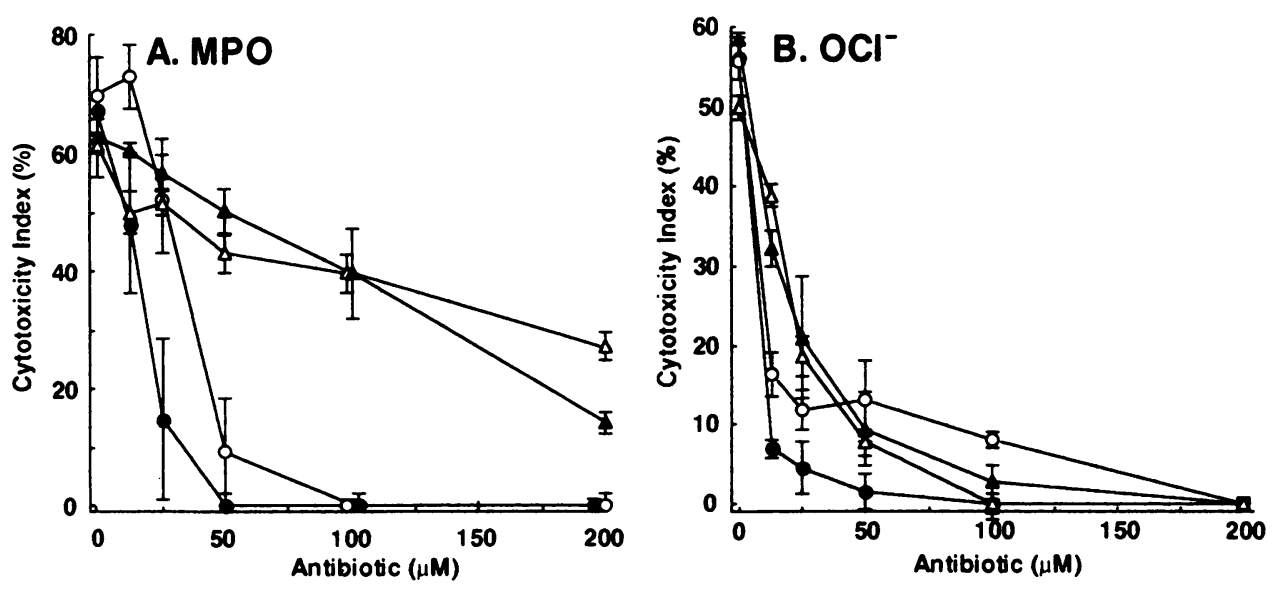

Figure 3. Comparison of cytoprotective properties of tobramycin $(\bullet)$, gentamicin $(0)$, ticarcillin $(\Delta)$, and ceftazidime $(\Delta)$ against oxidant injury. ${ }^{51} \mathrm{Cr}$-labeled AKD cells were incubated $1 \mathrm{~h}$ with various concentrations of the antibiotics in the presence of either $(A) 2.5 \mu \mathrm{g} / \mathrm{ml}$ myeloperoxidase or $(B)$ media alone. Subsequently, either $(A) 150$ $\mu \mathrm{M} \mathrm{H}_{2} \mathrm{O}_{2}$ or $(B) 150 \mu \mathrm{M} \mathrm{HOCl}$ was added to the culture media and the cells were incubated $7 \mathrm{~h}$ at $37^{\circ} \mathrm{C}$ to determine the cytotoxicity index. Each point represents the mean \pm SEM of at least three experiments performed in triplicate. 


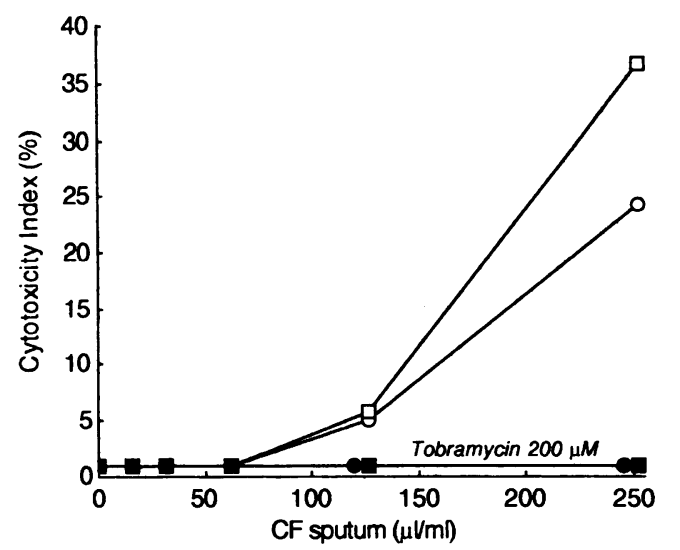

Figure 4. Protection of lung epithelial cells by tobramycin against $\mathrm{H}_{2} \mathrm{O}_{2}$ and sputum from two patients with cystic fibrosis. ${ }^{51} \mathrm{Cr}$-labeled cells were incubated with various concentrations of the treated sputum in the presence $(\bullet,-)$ ) or absence $(O, \square)$ of $200 \mu \mathrm{M}$ tobramycin. After $1 \mathrm{~h}$ incubation, $150 \mu \mathrm{M} \mathrm{H}_{2} \mathrm{O}_{2}$ was added to the media and the cells were incubated for $7 \mathrm{~h}$. At the end of the incubation, the supernatants were centrifuged, and the cytotoxicity index was determined from the ${ }^{51} \mathrm{Cr}$ measured in the culture supernatant. Incubation of sputum in the absence of $\mathrm{H}_{2} \mathrm{O}_{2}$ did not induce cytotoxicity. Each point represents triplicate cultures.

Incubation of each of the four antibiotics at a concentration of $200 \mu \mathrm{M}$ with $100 \mu \mathrm{M} \mathrm{HOCl}$ did not decrease the bactericidal activity of the antibiotics (data not shown).

Characterization of the $\mathrm{HOCl}$-aminoglycoside reaction product. The maximal absorbance of $\mathrm{HOCl}$ alone was observed at a wavelength of $291 \mathrm{~nm}$ (Fig. 6). However, in the presence of either tobramycin or gentamicin, the maximal absorbance was shifted to a wavelength of $252 \mathrm{~nm}$, as expected of chloramines derived from primary amines (20). Consistent with the knowledge that gentamicin has fewer primary amine groups than tobramycin (Fig. 1), the maximal absorbance at $252 \mathrm{~nm}$ of the gentamicin- $\mathrm{HOCl}$ solution was always lower than that of the tobramycin- $\mathrm{HOCl}$ solution.

Further evidence that chloramines were formed from the reaction of aminoglycosides and $\mathrm{HOCl}$ is shown in Fig. 7. Neither tobramycin nor gentamicin alone affected the 5-thio-2-nitrobenzoic acid concentration in a buffered solution (5-thio-2nitrobenzoic acid alone $=63.2 \pm 0.1 \mu \mathrm{M},+$ tobramycin $=62.4 \pm 0.2 \mu \mathrm{M},+$ gentamicin $=62.6 \pm 0.2, P>0.05$ all comparisons). As expected, the addition of $\mathrm{HOCl}$ oxidized the 5thio-2-nitrobenzoic acid solution as can be seen by the decrease in 5-thio-2-nitrobenzoic acid concentration, and the addition of aminoglycosides in the presence of $\mathrm{HOCl}$ further oxidized 5-thio-2-nitrobenzoic acid $(+\mathrm{HOCl}, 5$-thio-2-nitrobenzoic acid $=16.7 \pm 0.1 \mu \mathrm{M} ;+$ tobramycin $+\mathrm{HOCl}$, 5-thio-2-nitrobenzoic acid $=7.8 \pm 0.2 \mu \mathrm{M} ;+$ gentamicin $+\mathrm{HOCl}$, 5-thio-2nitrobenzoic acid $=8.4 \pm 0.3 \mu \mathrm{M} ; P<0.01$ tobramycin and gentamicin compared to $\mathrm{HOCl}$ alone). DMSO added to $\mathrm{HOCl}$ protected the 5-thio-2-nitrobenzoic acid against oxidation $(+\mathrm{HOCl}+\mathrm{DMSO}$, 5-thio-2-nitrobenzoic acid $=59.9 \pm 0.2 P$ $<0.001$ compared to $\mathrm{HOCl}$ without DMSO), but was unable to protect 5-thio-2-nitrobenzoic acid against oxidation from $\mathrm{HOCl}$ in the presence of either tobramycin (5-thio-2-nitrobenzoic acid $=8.0 \pm 0.2 \mu \mathrm{M}, P>0.20$ vs. without DMSO) or gentamicin (5-thio-2-nitrobenzoic acid $=8.1 \pm 0.1 \mu \mathrm{M}, P>0.20$ vs. without DMSO).
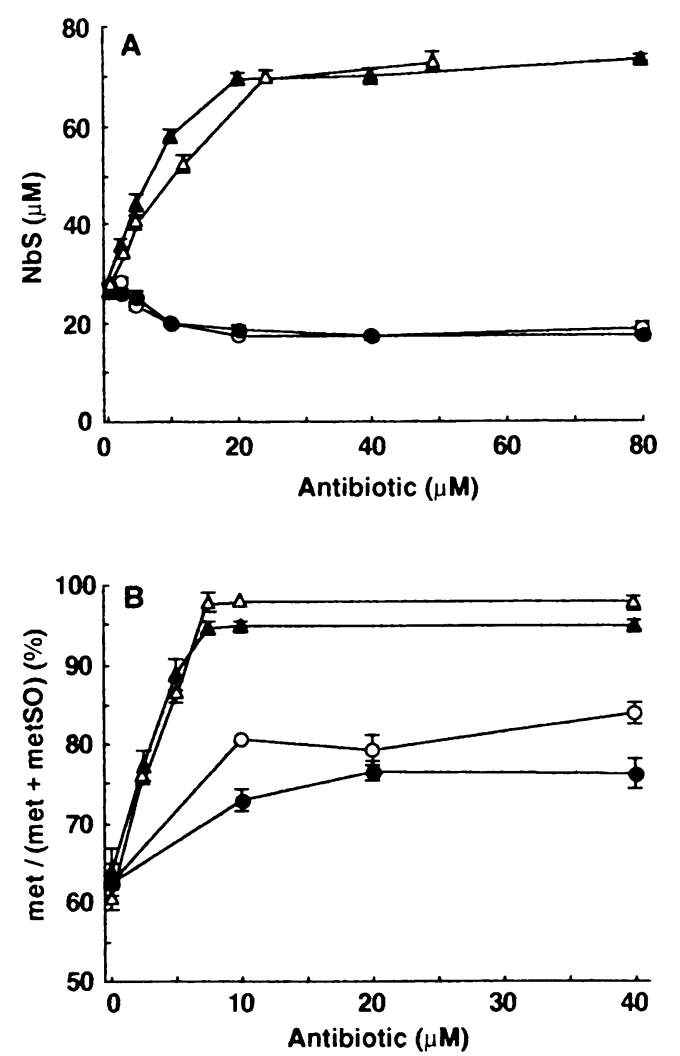

Figure 5. Ability of antibiotics to prevent $\mathrm{HOCl}$-induced oxidation of sulfhydryl groups and methionine. Ticarcillin $(\Delta)$, ceftazidime $(\Delta)$, gentamicin $(\circ)$, and tobramycin $(\bullet)$ at different concentrations were incubated with $40 \mu \mathrm{M} \mathrm{HOCl}$ in EBSS for $15 \mathrm{~min}$ at $25^{\circ} \mathrm{C}$ before the addition of either 5-thio-2-nitrobenzoic acid, or methionine. $(A)$ 5thio-2-nitrobenzoic acid $(80 \mu \mathrm{M})$ was added to the samples, for 15 $\min$, and the absorbance of the solutions was measured at $412 \mathrm{~nm}$ to determine the concentration of residual 5-thio-2-nitrobenzoic acid $(\mathrm{NbS})$. (B) Methionine ( $100 \mu \mathrm{M})$ was added to each sample, incubated for $15 \mathrm{~min}$, and subsequently the amounts of methionine ( $\mathrm{met}$ ) and methionine sulfoxide ( $m e t S O$ ) were determined by HPLC.

Partitioning of the aminoglycoside- $\mathrm{HOCl}$ reaction products between the organic and aqueous phases of an ethyl acetate $/ \mathrm{NaCl}$ gradient revealed that nearly all of the oxidizing equivalents mobilized to the aqueous phase, thus confirming the hydrophilic nature of the oxidant products (Table II).

\section{Discussion}

Epithelial cells of the upper and lower respiratory tract are exposed to high concentrations of extracellular myeloperoxidase in diseases such as the adult respiratory distress syndrome (ARDS), idiopathic pulmonary fibrosis (IPF), and CF $(11,18$, $24)$. The presence of oxidized $\alpha_{1}$-antitrypsin and of methionine sulfoxide in the bronchoalveolar lavage fluid of patients with ARDS and IPF, respectively, provides direct evidence of an excessive oxidant burden in vivo $(24,25)$. Furthermore, $\alpha_{1}$-antitrypsyin is inactive in the airway secretions of CF patients, an observation that may, at least in part, be explained by a high oxidant burden $(7,26)$. The present study documents that the aminoglycosides, ticarcillin and ceftazidime, all efficient anti-Pseudomonas aeruginosa antibiotics commonly used in the treatment of CF lung infections, have cytoprotec- 


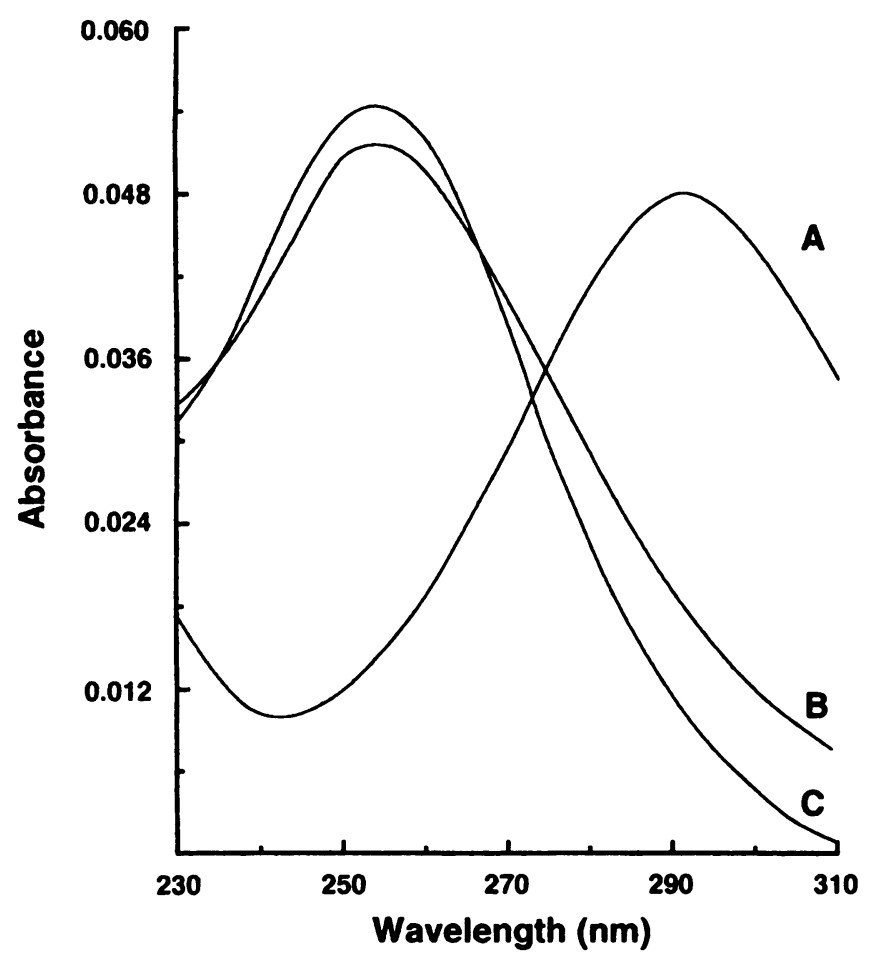

Figure 6. Absorbance spectra of $200 \mu \mathrm{M} \mathrm{HOCl}(A)$ alone, or in the presence of either $(B) 200 \mu \mathrm{M}$ gentamicin or $(C) 200 \mu \mathrm{M}$ tobramycin. All samples were incubated in EBSS at $25^{\circ} \mathrm{C}$ for $5 \mathrm{~min}$ before being scanned in the ultraviolet wavelength range. The reference cuvettes contained EBSS, gentamicin, and tobramycin, respectively.

tive properties against myeloperoxidase $/ \mathrm{H}_{2} \mathrm{O}_{2}$-mediated lung epithelial cell injury. In addition, tobramycin completely protected lung epithelial cells in vitro against injury from $\mathrm{CF}$ bronchial secretions and $\mathrm{H}_{2} \mathrm{O}_{2}$.

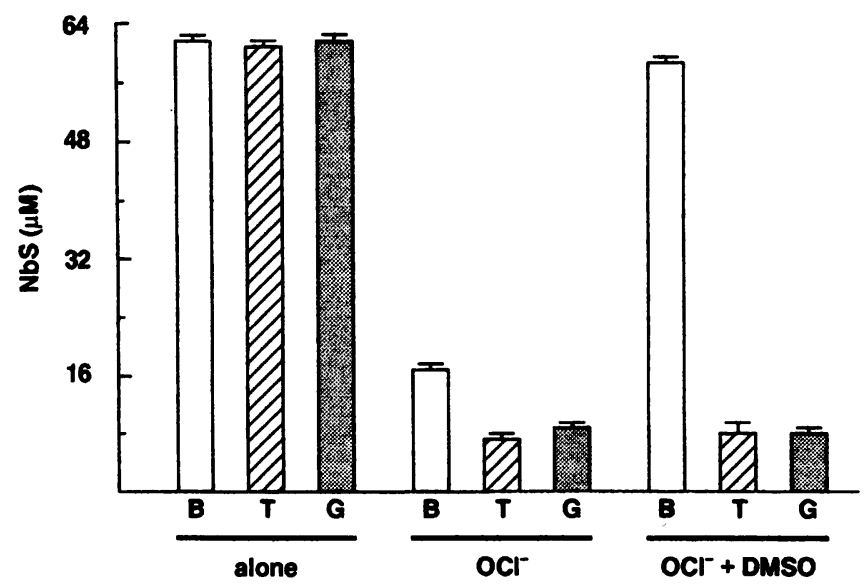

Figure 7. Evidence of chloramine formation from the reaction of $\mathrm{HOCl}$ with aminoglycosides. Phosphate buffered saline $(B), 200 \mu \mathrm{M}$ tobramycin $(T)$, and $200 \mu \mathrm{M}$ gentamicin $(G)$ were incubated either alone or in the presence of $40 \mu \mathrm{M} \mathrm{HOCl}$ for $15 \mathrm{~min}$. Subsequently, $200 \mu \mathrm{M}$ dimethylsulfoxide ( $D M S O$ ) was added to half of the samples containing $\mathrm{HOCl}$, for $15 \mathrm{~min}$, followed by the addition of $60 \mu \mathrm{M}$ 5-thio-2-nitrobenzoic acid to all samples for $5 \mathrm{~min}$. The residual 5thio-2-nitrobenzoic acid was quantitated from the absorbance of each sample at a wavelength of $412 \mathrm{~nm}$. Values represent the mean \pm SEM of five determinations.
Table II. Relative Hydrophilicity and Lipophilicity of Aminoglycoside Chloramines

\begin{tabular}{|c|c|c|}
\hline \multirow[b]{2}{*}{ Aminoglycoside } & \multicolumn{2}{|c|}{ Chloramines } \\
\hline & $\begin{array}{l}\text { Aqueous } \\
\text { phase }\end{array}$ & $\begin{array}{l}\text { Organic } \\
\text { phase }\end{array}$ \\
\hline & \multicolumn{2}{|c|}{$\mu M$} \\
\hline Tobramycin & $17.67 \pm 0.45(97)^{*}$ & $0.47 \pm 0.18$ \\
\hline Gentamicin & $17.46 \pm 0.53(92)$ & $1.63 \pm 0.16(8)$ \\
\hline
\end{tabular}

* Values represent the mean \pm SEM of five determinations. Numbers in parentheses represent percentage of total chloramines in both phases.

Myeloperoxidase and $\mathrm{H}_{2} \mathrm{O}_{2}$ added simultaneously to the lung epithelial cells caused little cytotoxicity, and it was found necessary to preincubate myeloperoxidase with the cells before the addition of $\mathrm{H}_{2} \mathrm{O}_{2}$ to induce maximal cytotoxicity. Myeloperoxidase is a highly cationic enzyme at physiologic $\mathrm{pH}$, with a pI > 10 (27). Based on studies of myeloperoxidase-mediated glomerular injury, it has been suggested that myeloperoxidase, bound to anionic sites, reacts with $\mathrm{H}_{2} \mathrm{O}_{2}$ to induce epithelial cell cytotoxicity (28). The presence of anionic sites, particularly negatively charged phospholipids (29), in the membranes of normal epithelial cells raises the possibility that binding of myeloperoxidase to the epithelial cell surface through charge interaction is necessary to induce maximal cytotoxicity.

It is of interest that although the four antibiotics tested in the present study were of equivalent efficacy in preventing $\mathrm{HOCl}$-induced cytotoxicity, the aminoglycosides were approximately fivefold more efficient than either ticarcillin or ceftazidime in preventing myeloperoxidase-mediated injury. None of the antibiotics were found to inhibit myeloperoxidase activity. Because of the cationic nature of the aminoglycosides (30), the likely explanation for this discrepancy is that the aminoglycosides bound to anionic cell surfaces as did myeloperoxidase and thus reacted with $\mathrm{HOCl}$ at its site of synthesis. In contrast, both ceftazidime and ticarcillin are organic anions at physiologic $\mathrm{pH}$ (31). Although ticarcillin and ceftazidime are potent $\mathrm{HOCl}$ scavengers, charge interactions may keep them away from areas of myeloperoxidase-dependent $\mathrm{HOCl}$ synthesis at anionic sites of the cell surface.

The mechanisms by which the aminoglycosides and the thioether-containing antibiotics, ticarcillin and ceftazidime, protected epithelial cells were different. Several lines of evidence suggest that the $\mathrm{HOCl}$-aminoglycoside reaction resulted in the formation of chloramines. First, the reaction product was capable of oxidizing the thiol group of 5-thio-2-nitrobenzoic acid, as would be expected of chloramines $(32,33)$. Second, both aminoglycosides shifted the maximal absorbance wavelength of $\mathrm{HOCl}$ from 291 to $252 \mathrm{~nm}$, a characteristic absorption peak for chloramines derived from primary amines (20). Third, whereas DMSO can reduce $\mathrm{HOCl}$, it is unable to reduce chloramines (20). Because DMSO could reduce $\mathrm{HOCl}$ alone but not in the presence of either aminoglycoside, these results further support the conclusion that chloramines were synthesized.

Chloramines, while retaining oxidant properties can be either cytotoxic or noncytotoxic, depending, in part, on their relative lipophilicity (32). In that the cell membrane is com- 
posed primarily of lipids, the lipophilic chloramines are generally more cytotoxic than the hydrophilic ones. Consistent with the polar, hydrophilic properties of aminoglycosides (34), the present studies indicate that the aminoglycoside- $\mathrm{HOCl}$ chloramines were mostly hydrophilic, a characteristic that likely contributed to render the aminoglycoside/ $\mathrm{HOCl}$ product innocuous. Since all aminoglycosides are rich in primary amines, other antibiotics of this class may have similar cytoprotective properties, but would not be expected to protect extracellular sulfhydryl and methionine groups against $\mathrm{HOCl}$-mediated oxidation.

Although the thioether-containing antibiotics were less efficient than aminoglycosides at protecting lung epithelial cells against myeloperoxidase-mediated injury, they were much more effective in preventing $\mathrm{HOCl}$-mediated oxidation of sulfhydryl groups and methionine. The anti-HOCl properties of ticarcillin and ceftazidime were identical in all assays, suggesting that similar mechanisms, such as thioether-mediated reduction of $\mathrm{HOCl}$, may have been involved for each antibiotic. These observations likely apply to many other penicillins and cephalosporins, all of which contain thioether groups in their thiazolidine and dihydrothiazine rings (35). It is of interest that the protection of methionine against oxidation has been shown to prevent the inactivation of the major anti-elastase protein, $\alpha_{1}$-antitrypsin (36). The thioether antibiotics may therefore help protect this essential molecule at sites of bacterial infection such as the CF lung.

The concept that certain drugs may react with myeloperoxidase-derived oxidants, and in particular $\mathrm{HOCl}$, is not new. It has been demonstrated that the sulfonamide antibiotics can decrease neutrophil candidacidal activity, likely by reacting with myeloperoxidase-derived $\mathrm{HOCl}(37)$. Kalyanaraman and Sohnle (38) also reported that foreign compounds, including many drugs, could react with products of the neutrophil myeloperoxidase system to generate toxic electrophilic molecules. Other investigators have demonstrated the scavenging of myeloperoxidase-derived $\mathrm{HOCl}$ by several anti-inflammatory drugs (39-41). However the observations from the present study differ in that they demonstrate the capacity of anti-Pseudomonas aeruginosa antibiotics to react with $\mathrm{HOCl}$ at a rate sufficient to protect lung epithelial cells and, for the thioethercontaining antibiotics, thiol groups and methionine from myeloperoxidase-dependent oxidation. These properties may be of particular interest in the therapy of CF lung disease, and of other infectious diseases of the lung, an organ which has an unexpected sensitivity to damage from $\mathrm{HOCl}$-derived oxidants (33).

The epithelial lining fluid of the normal lung contains many molecules that could potentially react with $\mathrm{HOCl}$ and act as endogenous antioxidants (15). If these naturally occuring antioxidants were always sufficient to prevent oxidation of essential lung molecules and epithelial cell death, then the antioxidant properties of antibiotics would be irrelevent. Evidence from the literature, such as methionine oxidation in IPF, and $\alpha_{1}$-antitrypsin oxidation in ARDS, suggests that the lung's naturally occuring antioxidants are not always sufficient to prevent oxidative damage and can be overwhelmed in neutrophilic inflammatory diseases $(24,25)$. These data would thus support the concept that antibiotic antioxidant properties may be clinically relevent. However, the current study does not confirm in vivo antioxidant efficacy, and further studies are needed.
The potential usefulness of these various classes of antibiotics as antioxidants may be modulated by several factors. First, significant antioxidant properties were observed at antibiotic concentrations of $\geq 25 \mu \mathrm{M}$. These relatively high concentrations may be difficult to maintain in tissues involved in purulent infections. Second, although aerosolization of large doses of antibiotics to the respiratory tract in CF is safe and may be a rational approach to maintain high concentrations of antibiotics in the airways (1-5), it is not clear that the antibiotics will reach the epithelial surface in areas of severe inflammation. Aerosol distribution in the $\mathrm{CF}$ lung has been shown to be less efficient in patients with more severe lung disease (42). However, the current study raises the question of whether efficient delivery of aerosolized antibiotics to the young CF patient, before severe airway damage has occurred, could significantly delay destructive lung disease by providing effective antioxidant protection. Third, the potential problem of selecting resistant bacteria by routinely administering aerosolized antibiotics for their antioxidant properties must be considered. While this is an important consideration, experience with aerosolized antibiotics in CF to date, would indicate that resistance has not prevented this form of therapy from providing definite benefits to selected CF patients (1-5). Finally, inhibition of the toxicity of the myeloperoxidase system may decrease the bactericidal activity of neutrophils (37). However, this may not be a major problem, because $(a)$ patients with a hereditary deficiency of myeloperoxidase are only slightly more susceptible to bacterial infections than are normal subjects $(43),(b)$ CF patients receiving aerosolized antibiotics do not demonstrate more severe lung infections (1-5), and $(c)$ the major pathogenic bacteria in the CF lung, the mucoid Pseudomonas aeruginosa, is already protected against myeloperoxidase-derived oxidants by an alginate coat that efficiently scavenges $\mathrm{HOCl}(44)$. Indeed, one may speculate that, if the mucoid Pseudomonas aeruginosa has adapted to its $\mathrm{HOCl}$-rich environment by protecting itself against $\mathrm{HOCl}$, then the $\mathrm{CF}$ airways may also benefit from anti$\mathrm{HOCl}$ protection.

In summary, aminoglycosides convert $\mathrm{HOCl}$ to noncytotoxic chloramines and protect lung epithelial cells against myeloperoxidase-mediated oxidant injury. Thioether containing antibiotics, specifically ticarcillin and ceftazidime, but likely many other penicillins and cephalosporins, are potent $\mathrm{HOCl}$ scavengers and protect lung epithelial cells, sulfhydryl groups, and methionine from $\mathrm{HOCl}$-mediated oxidation. These antioxidant properties of antibiotics may contribute to the protection of tissues involved in purulent infections, particularly the lung in patients with CF.

\section{Acknowledgments}

The authors thank Ginette Bilodeau and Marc Martel for excellent technical assistance.

This study was supported by a grant from the Canadian Cystic Fibrosis Foundation. Dr. Cantin is a scholar of the Fonds de la Recherche en Santé du Québec.

\section{References}

1. Hodson, M. E., A. R. L. Penketh, and J. C. Batten. 1981. Aerosol carbenicillin and gentamicin treatment of Pseudomonas aeruginosa infection in patients with cystic fibrosis. Lancet. II:1137-1139.

2. Wall, M. A., A. B. Terry, J. Eisenberg, M. McNamara, and R. Cohen. 1983 Inhaled antibiotics in cystic fibrosis. Lancet. I:1325. 
3. Stead, R. J., M. E. Hodson, and J. C. Batten. 1987. Inhaled ceftazidime compared with gentamicin and carbenicillin in older patients with cystic fibrosis infected with Pseudomonas aeruginosa. Br. J. Dis. Chest. 81:272-279.

4. Steinkamp, G., B. Tümmler, M. Gappa, A. Albus, J. Potel, G. Döring, and H. van der Hardt. 1989. Long-term tobramycin aerosol therapy in cystic fibrosis. Pediatr. Pulmonol. 6:91-98.

5. MacLusky, I. B., R. Gold, M. Corey, and H. Levison. 1989. Long-term effects of inhaled tobramycin in patients with cystic fibrosis colonized with Pseudomonas aeruginosa. Pediatr. Pulmonol. 7:42-48.

6. Høiby, N. 1974. Epidemiological investigations of the respiratory tract bacteriology in patients with cystic fibrosis. Acta Pathol. Microbiol. Scand. Sect. B. Microbiol. Immunol. 82:541-550.

7. Goldstein, W., and G. Döring. 1986. Lysosomal enzymes from polymorphonuclear leukocytes and protease inhibitors in patients with cystic fibrosis. Am. Rev. Respir. Dis. 134:49-56.

8. Suter, S., U. B. Schaad, L. Roux, U. E. Nydegger, and F. A. Waldvogel 1984. Granulocyte neutral proteases and Pseudomonas elastase as possible causes of airway damage in patients with cystic fibrosis. J. Infect. Dis. 149:523-531.

9. Jackowski, J. T., Z. S. Szepfalusi, D. A. Wanner, Z. S. Seybold, M. W. Sielczak, I. T. Lauredo, T. Adams, W. M. Abraham, and A. Wanner. 1991. Effects of $P$. aeruginosa-derived bacterial products on tracheal ciliary function: role of $\mathrm{O}_{2}$ radicals. Am. J. Physiol. 260 (Lung Cell. Mol. Physiol. 4):L61-L67.

10. Test, S. T., and S. J. Weiss. 1984. Quantitative and temporal characterization of the extracellular $\mathrm{H}_{2} \mathrm{O}_{2}$ pool generated by human neutrophils. J. Biol. Chem. 259:399-405.

11. Mohammed, J. R., B. S. Mohammed, L. J. Pawluk, D. M. Bucci, N. R. Baker, and W. B. Davis. 1988. Purification and cytotoxic potential of myeloperoxidase in cystic fibrosis sputum. J. Lab. Clin. Med. 112:711-720.

12. Schraufstätter, I. U., K. Browne, A. Harris, P. A. Hyslop, J. H. Jackson, O. Quehenberger, and C. G. Cochrane. 1990. Mechanisms of hypochlorite injury of target cells. J. Clin. Invest. 85:554-562.

13. Thomas, E. L., M. M. Jefferson, and M. B. Grisham. 1982. Myeloperoxidase-catalyzed incorporation of amines into proteins: role of hypochlorous acid and dichloramines. Biochemistry. 21:6299-6308.

14. Kniazeff, A. J., G. D. Stoner, L. Terry, R. M. Wagner, and R. D. Hoppenstand. 1976. Characterization of epithelial cells cultured from feline lung. Lab. Invest. 34:495-500.

15. Cantin, A. M., G. A. Fells, R. C. Hubbard, R. G. Crystal. 1990. Antioxidant macromolecules in the epithelial lining fluid of the normal human lower respiratory tract. J. Clin. Invest. 86:962-971.

16. Matheson, N. R., P.S. Wong, and J. Travis. 1981. Isolation and properties of human neutrophil myeloperoxidase. Biochemistry. 20:325-330.

17. Schultz, J., and H. W. Shmukler. 1964. Myeloperoxidase of the leukocyte of normal human blood. II. Isolation, spectrophotometry, and amino acid analysis. Biochemistry. 3:1234-1238.

18. Cantin, A. M., S. L. North, G. A. Fells, R. C. Hubbard, and R. G. Crystal. 1987. Oxidant-mediated epithelial cell injury in idiopathic pulmonary fibrosis. $J$. Clin. Invest. 79:1665-1673.

19. Karnofsky, J. R., J. Wright, G. E. Miles-Richardson, and A. I. Tauber. 1984. Biochemical requirements for singlet oxygen production by purified myeloperoxidase. J. Clin. Invest. 74:1489-1495.

20. Thomas, E. L., M. B. Grisham, and M. M. Jefferson. 1986. Preparation and characterization of chloramines. Methods Enzymol. 132:569-585.

21. Turnell, D. C., and J. D. H. Cooper. 1982. Rapid assay for amino acids in serum or urine by pre-column derivatization and reversed-phase liquid chromatography. Clin. Chem. 28:527-531.

22. Thomas, E. L. 1981. Lactoperoxidase-catalyzed oxidation of thiocyanate: equilibria between oxidized forms of thiocyanate. Biochemistry. 20:3273-3280.
23. Snedecor, G. W., and W. G. Cochrane. 1980. Statistical Methods, 7th edition. Iowa State University Press. Ames, IA.

24. Cochrane, C. G., R. Spragg, and S. D. Revak. 1983. Pathogenesis of the adult respiratory distress syndrome; evidence of oxidant activity in bronchoalveolar lavage fluid. J. Clin. Invest. 71:754-761.

25. Maier, K., L. Leuschel, and U. Costabel. 1991. Increased levels of oxidized methionine residues in bronchoalveolar lavage fluid proteins from patients with idiopathic pulmonary fibrosis. Am. Rev. Respir. Dis. 143:271-274.

26. Cantin, A., G. Bilodeau, and R. Bégin. 1989. Granulocyte elastase-mediated proteolysis of alpha $a_{1}$-antitrypsin in cystic fibrosis bronchopulmonary secretions. Pediatr. Pulmonol. 7:12-17.

27. Agner, K. 1941. Verdoperoxidase. A ferment isolated from leukocytes. Acta Physiol. Scand. 2(Suppl. 8):1-62.

28. Johnson, R. J., W. G. Couser, E. Y. Chi, S. Adler, and S. J. Klebanoff. 1987. New mechanism for glomerular injury: myeloperoxidase-hydrogen peroxide-halide system. J. Clin. Invest. 79:1379-1387.

29. Sastrasinh, M., T. C. Knauss, J. M. Weinberg, and H. D. Humes. 1982. Identification of the aminoglycoside binding site in rat renal brush border membranes. J. Pharmacol. Exp. Ther. 222:350-358.

30. Humes, H. D., J. M. Weinberg, and T. C. Knauss. 1982. Clinical and pathophysiologic aspects of aminoglycoside nephrotoxicity. Am. J. Kidney Dis 2:5-29.

31. Kelly, H. W., and C. Lovato. 1984. Antibiotic use in cystic fibrosis. Drug Intell. Clin. Pharm. 18:772-783.

32. Test, S. T., and S. J. Weiss. 1986. The generation and utilization of chlorinated oxidants by human neutrophils. Adv. Free Rad. Biol. Med. 2:91-116.

33. Weiss, S. J. 1989. Tissue destruction by neutrophils. N. Engl. J. Med. 320:365-376.

34. Pechere, J. C., and R. Dugal. 1979. Clinical pharmacokinetics of aminoglycoside antibiotics. Clin. Pharmacokinet. 4:170-199.

35. Thompson, R. L. 1977. The cephalosporins. Mayo Clin. Proc. 52:625630.

36. Johnson, D., J. Travis. 1979. The oxidative inactivation of human alpha1-proteinase inhibitor: further evidence for methionine at the reactive center. $J$. Biol. Chem. 254:4022-4026.

37. Lehrer, R. I. 1971. Inhibition by sulfonamides of the candidacidal activity of human neutrophils. J. Clin. Invest. 50:2498-2505.

38. Kalyanaraman, B., and P. G. Sohnle. 1985. Generation of free radical intermediates from foreign compounds by neutrophil-derived oxidants. J. Clin. Invest. 75:1618-1622.

39. Dougherty, H. W., A. Hen, F. A. Kuehl Jr. 1980. The role of polymorphonuclear peroxidase-dependent oxidants in inflammation. Agents Actions. 7(Suppl.):165-173.

40. Pekoe, G., K. Van Dyke, D. Peden, H. Mengoli, and D. English. 1982. Antioxidation theory of non-steroidal anti-inflammatory drugs upon the inhibition of luminol-enhanced chemiluminescence from the myeloperoxidase reaction. Agents Actions. 12:371-376.

41. Wasil, M., B. Halliwell, C. P. Moorhouse, D. C. S. Hutchison, and H. Baum. 1987. Biologically-significant scavenging of the myeloperoxidase-derived oxidant hypochlorous acid by some anti-inflammatory drugs. Biochem. Pharmacol. 36:3847-3850.

42. Alderson, P. O., R. H. Secker-Walker, D. B. Strominger, J. Markham, and R. L. Hill. 1974. Pulmonary deposition of aerosols in children with cystic fibrosis. J. Pediatr. 84:479-484.

43. Parry, M. F., R. K. Root, J. A. Metcalf, K. K. Delaney, L. S. Kaplow, W. J. Richar. 1981. Myeloperoxidase deficiency: prevalence and clinical significance. Ann. Intern. Med. 95:293-301.

44. Learn, D. B., E. P. Brestel, and S. Seetharama. 1987. Hypochlorite scavenging by Pseudomonas aeruginosa alginate. Infect. Immunol. 55:1813-1818. 